\title{
Pengaruh Lama Waktu Perendaman Telur dalam Larutan Hormon Tiroksin (T4) Terhadap Daya Tetas, Pertumbuhan dan Kelangsungan Hidup Larva Ikan Gurami (Osphronemus gouramy)
}

\author{
Effect of Egg Soaking Time in Thyroxine Hormone Solution (T4) on \\ Hatchability, Growth and Survival of Gouramy (Osphronemus gouramy) Larvae
}

Merry Ayu Andani, Sri Marnani*, Taufik Budhi Pramono

Program Studi Akuakultur Fakultas Perikanan dan Ilmu Kelautan, Universitas Jenderal Soedirman, Purwokerto, 53123, Indonesia

*Korespondensi: srimarnanisuwarto@yahoo.co.id

\begin{abstract}
ABSTRAK
Hormon tiroksin merupakan hormon yang mampu menurunkan tingginya mortalitas dan meningkatkan pertumbuhan ikan. Penelitian ini bertujuan untuk mengetahui pengaruh lama waktu perendaman telur dalam larutan hormon tiroksin dan waktu yang baik untuk meningkatkan daya tetas, pertumbuhan, dan kelangsungan hidup larva gurami. Metode yang digunakan adalah eksperimen di laboratorium dengan rancangan acak lengkap. Perlakuan lama waktu perendaman telur dalam larutan hormon tiroksin dengan dosis $0.1 \mathrm{mg} / \mathrm{L}$ yaitu $0,8,16,24$ dan 32 jam. Tiap perlakuan dilakukan tiga ulangan. Hasil dari penelitian menunjukkan bahwa lama waktu perendaman tidak berpengaruh terhadap daya tetas, namun berpengaruh terhadap pertumbuhan panjang dan kelangsungan hidup larva gurami (O. gouramy). Lama waktu perendaman terbaik adalah 16 - 24 jam dengan nilai daya tetas $97.67-99.00 \%$, pertumbuhan panjang mutlak $6.50-6.92 \mathrm{~mm}$, pertumbuhan panjang relatif $4.93-5.25 \%$, dan kelangsungan hidup sebesar $91.26-92.15 \%$.
\end{abstract}

Kata kunci: ikan gurami, hormon tiroksin, daya tetas, pertumbuhan, kelangsungan hidup, perendaman.

\begin{abstract}
The thyroxine hormone is a hormone that can reduce high mortality and increase fish growth. The aim of this study was to determine the effect of long immersion time in the thyroxine hormone solution and a good time to increase hatching rate, growth and survival rate of Gourami larvae. The method used was a laboratory experiment with a completely randomized design. Treatment of egg immersion time in thyroxine hormone solution with a dose of $0.1 \mathrm{mg} / \mathrm{L}$, namely $0,8,16,24$ and 32 hours. Each treatment was carried out three replications. The results of the study indicated that the immersion time did not affect hatching rate, but it did affect the length growth and survival of gourami larvae $(O$. gouramy). The good immersion time is $16-24$ hours with hatching rate values $97.67-$ $99.00 \%$, absolute length growth of $6.50-6.92 \mathrm{~mm}$, relative length growth of $4.93-5.25 \%$, and survival rate of $91.26-92.15 \%$.
\end{abstract}

Keywords: gourami fish, thyroxine hormone, hatching rate, growth, survival rate, dipping 


\section{PENDAHULUAN}

Ikan gurami (Osphronemus gouramy) merupakan jenis ikan air tawar asli Indonesia yang memiliki nilai ekonomis penting, telah lama dibudidayakan dan dikonsumsi oleh masyarakat (Kurniawan et al., 2014; Arifin et.al., 2017). Produksi benih ikan gurami di Indonesia mengalami peningkatan setiap tahunnya, akan tetapi belum dapat memenuhi permintaan pasar secara kuantitas maupun kualitas. Kendala terbesar yang dihadapi untuk pemenuhan kebutuhan benih ikan gurami adalah tingginya mortalitas telur dan larva sampai benih ukuran $1 \mathrm{~cm}$ (Ulpah et al., 2017; Pranata et al., 2017; Budiana dan Rahardja, 2018).

Kegagalan produksi pada usaha pembenihan akibat mortalitas yang tinggi erat kaitannya dengan fase kritis pada stadia embrio dan larva (Soedibya dan Pramono, 2018). Permasalahan yang umumnya terjadi pada stadia embrio dan larva adalah proses perkembangan embryogenesis dan organogenesis yang tidak sempurna, metamorfosis yang tidak seragam serta pertumbuhan yang lambat (Dewi, 2006; Pramono dan Marnani, 2012). Upaya yang dapat dilakukan untuk mengatasi kendala-kendala tersebut adalah dengan pendekatan rekayasa hormonal menggunakan hormon tiroksin.

Hormon tiroksin atau tetraiodotironin (T4) dikenal memiliki beberapa peranan penting dalam perkembangan awal daur hidup embryogenesis (Power et.al., 2001), keseimbangan fisiologi (Salvatore, 2011), perkembangan dan reproduksi ikan (Blanton dan Specker, 2007). pertumbuhan, peningkatan laju konsumsi oksigen dan oksidasi makanan, serta mempercepat proses metamorfosis (Khalil et al., 2011; Dolomatov et.al., 2013).

Beberapa peneliti telah menerapkan pada sebagian jenis ikan seperti benih ikan gurami Osphronemus gouramy (Kurniawan et.al., 2014), ikan lais Kryptoterus lais (Agusnimar dan
Rosyadi, 2015), ikan betok Anabas testudineus (Pebriyanti et al., 2015), ikan pawas Osteochilus hasselti (Susanti et.al., 2016), ikan mas koki Carasius auratus (Oktaviani et al., 2017), ikan gabus Channa striata (Muslim et.al., 2019; Pasaribu et al., 2019), ikan nila Oreochromis niloticus (Andriawan et.al., 2020).

Aplikasi perendaman hormon tiroksin pada ikan gurami baru dilakukan pada stadia benih dengan dosis yang berbeda (Kurniawan et al., 2014). Hasil penelitian tersebut terbukti dosis perendaman $1.5 \mathrm{mg} / 3 \mathrm{~L}$ dapat meningkatkan pertumbuhan panjang mutlak sebesar $0.93 \mathrm{~cm}$ dan tingkat kelulushidupan benih gurami sebesar $100 \%$. Peningkatan pertumbuhan dan kelangsungan hidup larva ikan Gurami dengan perendaman hormon tiroksin dapat dioptimalkan melalui lama waktu perendaman telur atau larva (Pasaribu et.al., 2019; Andriawan et.al., 2020). Perbedaan lama waktu perendaman telur diharapkan hormon trioksin dapat terserap lebih banyak oleh telur dan selanjutnya pada larva ikan Gurami. Penelitian ini bertujuan untuk mengetahui pengaruh lama waktu perendaman telur dalam larutan hormon tiroksin terhadap daya tetas telur, pertumbuhan panjang, dan kelangsungan hidup larva gurami (O. gouramy).

\section{MATERI METODE}

\section{Pelaksanaan penelitian}

Penelitian ini dilakukan di Laboratorium Hatchery dan Teknologi Akuakultur, Fakultas Perikanan dan Ilmu Kelautan, Universitas Jenderal Soedirman. Metode penelitian ini adalah metode eksperimental dengan menggunakan Rancangan Acak Lengkap (RAL), 5 perlakuan dan 3 kali ulangan. Perlakuan yang diuji adalah perendaman telur ikan gurami (O. gouramy) dalam hormon tiroksin dengan lama waktu perendaman yang berbeda. Perbedaan perlakuan yang digunakan yaitu P1 (0 jam), P2 (8 jam), P3 (16 jam), P4 (24 
jam), P5 (32 jam) dengan masing-masing perlakuan diulang sebanyak 3 (tiga) kali.

\section{Penyediaan Hormon Tiroksin}

Hormon tiroksin yang digunakan berbentuk tablet hormon tiroksin merk Euthyrox. Sebelum digunakan, hormon tiroksin tablet dihaluskan menggunakan mortar dan pastle. Kandungan bahan aktif hormon tiroksin pada label yaitu $0.10 \mathrm{mg}$ per tablet. Dosis yang digunakan dalam penelitian ini berdasarkan Alkatiri (2016) yaitu sebesar $0.10 \mathrm{mg} / \mathrm{L}$, sehingga 1 tablet hormon diencerkan dengan air sebanyak 1 liter air untuk mendapatkan dosis tersebut.

\section{Perendaman Telur dengan Larutan Hormon Tiroksin}

Sebanyak 100 butir telur ikan Gurami untuk masing-masing perlakuan direndam dalam wadah perendaman yang berisi larutan hormon tiroksin. Selesai lama waktu perendaman, telur dipindahkan ke dalam wadah pemeliharaan dengan volume 3 Liter air hingga telur menetas. Daya tetas telur (hatching rate) masing-masing perlakuan dihitung dengan perbandingan telur yang menetas dan telur sampel dikalikan $100 \%$.

Pemeliharaan Larva Ikan gurami (O. gouramy) Pasca Perendaman Hormon Tiroksin

Larva ikan gurami pasca perendaman hormon tiroksin dipelihara hingga umur 21 hari. Setelah kuning telur habis, larva ikan Gurami diberi cacing sutra sampai akhir pemeliharaan. Pemberian pakan dilakukan 4 kali sehari yaitu pagi, siang, sore dan malam hari secara ad libitum.

\section{Pengamatan Pertumbuhan Larva Ikan Gurami Pasca Perendaman Hormon Tiroksin}

Pertumbuhan yang diamati meliputi panjang mutlak dan panjang relatif. Pengukuran pertumbuhan panjang menggunakan jangka sorong dengan ketelitian $0.1 \mathrm{~mm}$. Panjang mutlak dihitung dari selisih rerata panjang total tubuh pada akhir pemeliharaan (Lt) dan awal pemeliharaan (L0). Panjang relatif merupakan persentase pertumbuhan yang dihitung dari selisih rerata panjang total tubuh pada akhir pemeliharaan (Lt) dan awal pemeliharaan (L0) dibandingkan interval waktu pemeliharaan (Zooneveld et al., 1991)

\section{Abnormalitas dan Kelangsungan Hidup Larva Ikan Gurami Pasca Perendaman Hormon Tiroksin}

Nilai abnormalitas dan kelangsungan hidup larva ikan gurami pasca perendaman dilakukan diakhir pemeliharaan dengan menggunakan perbandingan jumlah larva abnormal dengan jumlah larva normal dikalikan $100 \%$. Nilai kelangsungan hidup ikan dihitung dengan perbandingan jumlah larva ikan pada akhir pemeliharaan dengan jumlah larva pada awal pemeliharaan.

\section{HASIL DAN PEMBAHASAN}

\section{Daya Tetas Telur Ikan Gurami dengan Perbedaan Lama Waktu Perendaman Hormon Tiroksin}

Berdasarkan hasil penelitian, rerata daya tetas telur ikan gurami yang direndam dalam larutan hormon tiroksin dengan dosis $0.1 \mathrm{mg} / \mathrm{L}$ dengan lama waktu berbeda disajikan pada Gambar 1 .

Hasil analisis sidik ragam (ANOVA) menunjukan bahwa perlakuan perbedaan lama waktu perendaman telur ikan Gurami dalam larutan hormon tiroksin tidak berpengaruh nyata terhadap daya tetas telur $(\mathrm{P}>0.05)$. Walaupun hasil penelitian ini tidak menunjukkan pengaruh yang nyata terhadap daya tetas telur, diduga hormon tiroksin tetap masuk ke dalam telur melalui difusi secara pasif dan berperan dalam proses embriogenesis. Hal ini diperkuat oleh hasil penelitian Yamano (2005) yang menemukan adanya penurunan kadar hormon tiroid dalam 
telur selama perkembangan embryogenesis dan sejumlah kadar hormon tiroid pada telur yang tidak terbuahi.

Rerata persentase daya tetas telur ikan gurami yang direndam dengan hormon tiroksin pada penelitian ini untuk semua perlakuan yaitu berkisar antara 97.33-99.00\%. Rerata persentase daya tetas telur dalam penelitian ini relatif cukup tinggi dibandingkan dengan daya tetas telur ikan Mas Koki (Carasius auratus) yang direndam hormon tiroksin dosis $0.1 \mathrm{mg} / \mathrm{L}$ dengan waktu perendaman 0 jam, 8 jam, dan 16 jam, yaitu di bawah $55 \%$ daya tetasnya, sedangkan untuk waktu perendaman 24 jam hanya $77.67 \%$ (Manurung et.al., 2017). Penelitian ini memperkuat pendapat Nayak et al. (2004) bahwa hormon tiroksin memiliki peranan proses embriogenesis dan organogenesis serta meningkatkan daya tetas telur ikan.

\section{Pertumbuhan Panjang Mutlak Larva}

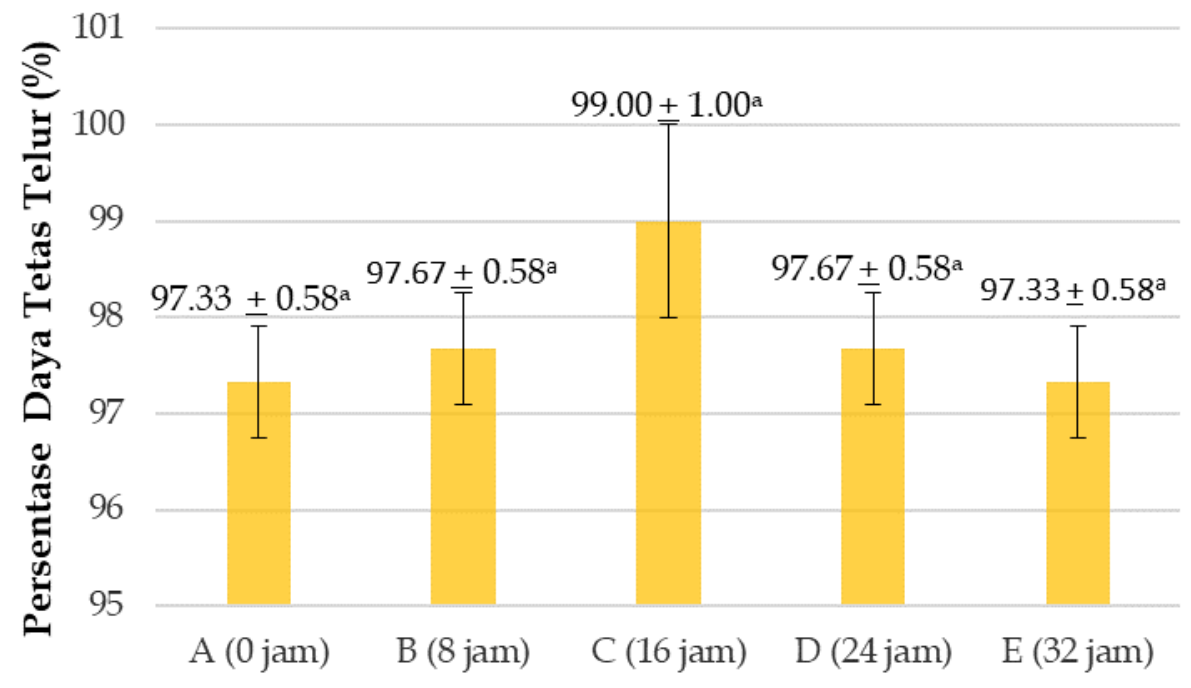

\section{- Waktu Perendaman}

Gambar 1. Grafik Rerata Daya Tetas Telur Setelah Dilakukan Perendaman Hormone Tiroksin $0.1 \mathrm{mg} / \mathrm{L}$ Dengan Waktu Berbeda. Angka yang diikuti huruf kecil superscript yang sama menunjukan tidak berbeda nyata $(\mathrm{P}>0,05)$. 
Pasaribu et al. (2019) melaporkan bahwa semakin lama waktu perendaman dalam larutan hormon tiroksin (36 jam), pertumbuhan panjang mutlak larva ikan gabus (Channa striata) juga semakin tinggi $(3.3 \mathrm{~cm})$ Sedangkan pada larva ikan betok (Anabas testudineus) diperoleh pertumbuhan panjang tertinggi pada perlakuan 48 jam sebesar $23.04 \mathrm{~mm}$

Rerata pertumbuhan panjang mutlak terendah dalam penelitian ini, diperoleh pada perlakuan A (kontrol) yaitu sebesar $3.77 \pm 0.01 \mathrm{~mm}$, sedangkan rerata pertumbuhan panjang mutlak tertinggi ada pada perlakuan perendaman 16 jam sebesar $6.92 \pm 0.01 \mathrm{~mm}$. Nilai pertumbuhan panjang mutlak larva yang diberi perlakuan lebih tinggi dibandingkan dengan kontrol. Hal ini diduga karena hormon tiroksin yang telah masuk ke dalam telur dan selanjutnya ke larva dapat meningkatkan proses metabolisme tubuh sehingga dapat meningkatkan pertumbuhan (Nayak et al. 2004; Setiaji dan Johan, 2012). Peningkatan proses metabolisme larva ikan akibat perendaman hormon tiroksin terkait dengan aktifitas mRNA yang mampu meningkatkan kecepatan sintesis protein dan selanjutnya berpengaruh terhadap peningkatan retensi protein
(Pebriyanti et al., 2015). Pertumbuhan panjang larva ikan pada penelitian ini dan beberapa penelitian lain yang sudah dilakukan menunjukan hasil yang berbeda-beda. Hasil yang berbeda terkait dengan efektifitas kerja dari hormon tiroksin yang sangat tergantung pada dosis, tahap perkembangan dan jenis ikan (Power et al., 2001).

dalam tubuh untuk pertumbuhan (Susanti et.al., 2016).

\section{Pertumbuhan Panjang Relatif Larva Gurami}

Perlakuan lama waktu perendaman telur yang berbeda dalam hormon tiroksin terhadap pertumbuhan panjang relatif berpengaruh nyata $(\mathrm{P}<0.05)$. Hasil uji lanjut beda nyata jujur (BNJ) menunjukkan bahwa pertumbuhan panjang relatif pada perlakuan lama waktu perendaman hormon tiroksin memiliki perbedaan yang nyata dengan kontrol. Lama waktu perendaman hormon tiroksin 8 jam berbeda nyata dengan perlakuan 16, 24 dan 32 jam, sedangkan waktu perendaman 16 jam tidak berbeda nyata dengan 24 jam dan berbeda nyata dengan lama waktu perendaman 32 jam (Gambar 2).

Tabel 1. Pertumbuhan Panjang Larva Gurami Setelah Dilakukan Perendaman Hormon Tiroksin 0.1 mg/L Dengan Lama Waktu Berbeda

\begin{tabular}{ccc}
\hline Perlakuan & \multicolumn{2}{c}{ Hasil Pertumbuhan } \\
\cline { 2 - 3 } & Panjang Mutlak (mm) & $\begin{array}{c}\text { Panjang Relatif } \\
\text { (\% panjang tubuh per hari) }\end{array}$ \\
\hline 0 jam & $3.77 \pm 0.1^{\mathrm{a}}$ & $2.822 \pm 0.08^{\mathrm{a}}$ \\
8 jam & $5.34 \pm 0.2^{\mathrm{b}}$ & $4.086 \pm 0.17^{\mathrm{b}}$ \\
16 jam & $6.92 \pm 0.09^{\mathrm{c}}$ & $5.253 \pm 0.05^{\mathrm{c}}$ \\
24 jam & $6.50 \pm 0.09^{\mathrm{c}}$ & $4.932 \pm 0.08^{\mathrm{cd}}$ \\
32 jam & $6.16 \pm 0.15^{\mathrm{d}}$ & $4.725 \pm 0.17^{\mathrm{d}}$ \\
\hline
\end{tabular}

Keterangan : Data pertumbuhan panjang merupakan hasil rata-rata $(\bar{x} \pm \mathrm{SD})$. Angka yang diikuti huruf kecil superscript yang berbeda pada kolom yang sama menunjukan perbedaan signifikan $(\mathrm{P}<0.5)$ 


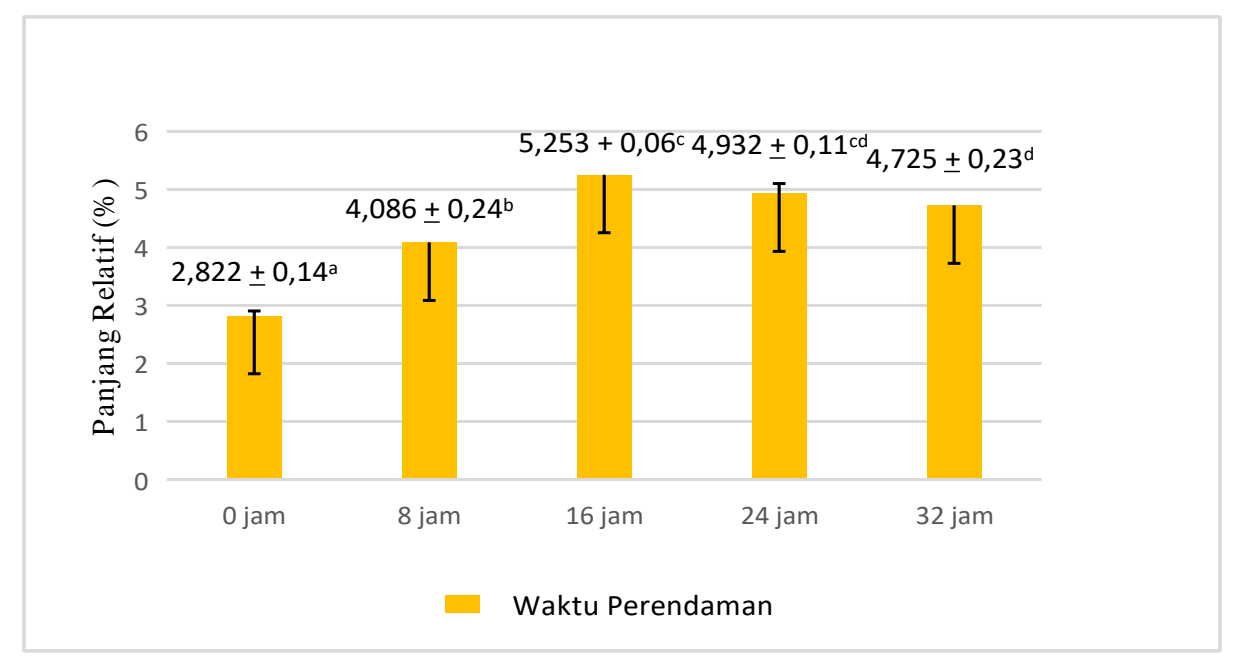

Gambar 2. Grafik Pertumbuhan Panjang Relatif Setelah Dilakukan Perendaman Hormon tiroksin $0.1 \mathrm{mg} / \mathrm{L}$ Dengan Waktu Berbeda

Rerata pertumbuhan panjang relatif terendah ada pada perlakuan A (kontrol) sebesar $2.822 \pm 0.14 \%$. Sedangkan rerata pertumbuhan panjang relatif tertinggi ada pada perlakuan $\mathrm{C}$ (perendaman selama 16 jam) sebesar $6.92 \pm 0.01 \%$. Tingginya pertumbuhan panjang relatif larva yang diberi perlakuan perendaman dengan hormon tiroksin dibanding dengan kontrol menunjukkan bahwa hormon tiroksin yang masuk ke dalam tubuh larva membantu metabolisme dan meningkatkan pertumbuhan. Hal ini sesuai dengan pernyataan Lam (1980) yang menyatakan bahwa hormon tiroksin mampu meningkatkan pertumbuhan dan perkembangan larva.

\section{Abnormalitas larva}

Persentase larva ikan gurami yang abnormal pada masing-masing perlakuan sangat kecil, bahkan pada perlakuan kontrol dan lama waktu perendaman telur 16 Jam tidak ditemukan larva abnormal (Tabel 2).
Tabel 2. Abnormalitas Larva Gurami Larva Gurami Setelah Dilakukan Perendaman Hormon Tiroksin $0.1 \mathrm{mg} / \mathrm{L}$ Dengan Waktu Berbeda

\begin{tabular}{cc}
\hline Perlakuan & Hasil (\%) \\
\hline A 0 jam & 0,0 \\
B 8 jam & 0,4 \\
C 16 jam & 0,0 \\
D 24 jam & 0,3 \\
E 32 jam & 0,4 \\
\hline
\end{tabular}

Abnormalitas yang ditemukan pada saat pengamatan, terdapat larva yang tidak memiliki sirip ekor (Gambar 3). Hasil penelitian ini menemukan bahwa perendaman dalam hormon tiroksin yang terlalu lama menyebabkan hormon tiroksin yang terserap ke dalam tubuh melebihi kebutuhan fisiologis normal. Kejadian ini dikenal juga dengan istilah hipertiroidisme (Pasaribu et al., 2019). Hal ini diperkuat dengan pernyataan Nayak et al. (2004) bahwa telur yang direndam dalam tiroksin menghasilkan larva yang abnormal lebih banyak dibandingkan dengan yang tidak direndam. 


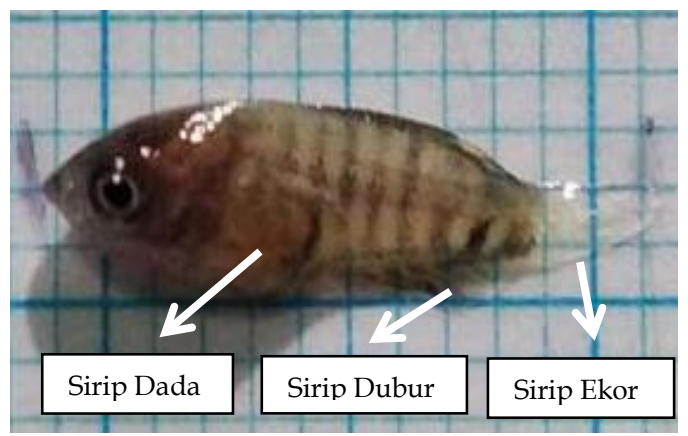

Larva Normal

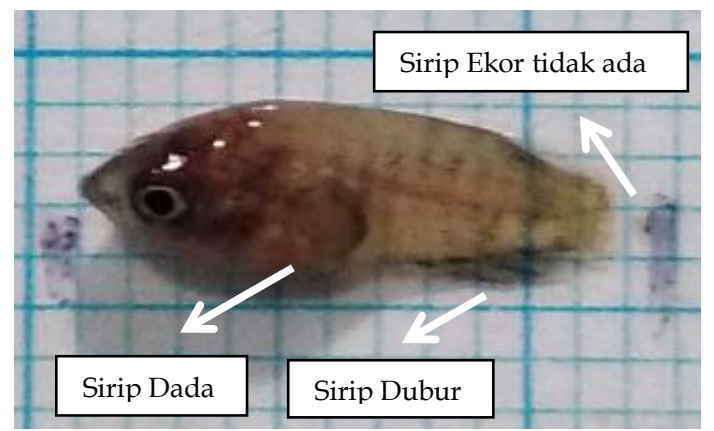

Larva Abnormal

Gambar 3. Perbandingan larva ikan gurami yang abnormal dan normal

\section{Kelangsungan Hidup Larva (Survival Rate)}

Berdasarkan hasil penelitian, rerata presentase kelangsungan hidup larva gurami yang direndam dalam larutan hormon tiroksin dengan dosis 0.1 $\mathrm{mg} / \mathrm{L}$ setelah pemeliharaan selama 21 hari disajikan pada Gambar 4.

Hasil analisis sidik ragam (ANOVA) menunjukan bahwa perlakuan lama waktu perendaman telur yang berbeda dalam larutan hormon tiroksin berpengaruh nyata terhadap kelangsungan hidup larva gurami $(\mathrm{P}<0.05)$. Hasil uji lanjut beda nyata jujur (BNJ) menunjukkan bahwa kelangsungan hidup larva pada perlakuan 0 jam (kontrol) tidak berbeda nyata dengan perlakuan lama waktu perendaman 8 dan 16 jam, akan tetapi berbeda yang nyata dengan perlakuan 24 jam dan 32 jam (Gambar 4). Kelangsungan hidup larva ikan gurami pada penelitian semakin tinggi seiring dengan lama waktu perendaman telur dalam larutan hormon tiroksin, hingga mencapai titik optimum pada perlakuan lama perendaman 16 dan 24 jam, kemudian menurun pada perlakuan 32 jam. Kondisi serupa terjadi pada penelitian Pebriyanti et al (2015), dimana waktu yang paling efektif untuk meningkatkan kelulushidupan larva ikan betok yaitu 24 jam dengan nilai kelangsungan hidup 85,78, sedangkan pada waktu perendaman 48 jam dan 72 jam nilai kelulushidupan larva sebesar $82,22 \%$ dan $72 \%$. Hasil yang berbeda dengan yang dilaporkan oleh Manurung et al. (2017), dimana waktu perendaman hormon tiroksin tidak berpengaruh terhadap nilai kelulushidupan larva. Hasil rerata persentase kelangsungan hidup larva mas koki dengan waktu perendaman 0 jam, 8 jam, 16 jam, dan 24 jam keseluruhan diatas $90 \%$.

Tingginya kelangsungan hidup larva gurami pada penelitian ini diduga akibat penyerapan hormon tiroksin yang mampu meningkatkan ketahanan tubuh. Hal ini sesuai pernyataan Matty (1985) dalam Fitriana (2002) bahwa perendaman hormon tiroksin pada dosis yang sesuai dapat meningkatkan daya tahan tubuh terhadap lingkungan. Andriawan et al. (2020) melaporkan bahwa hormon tiroksin mampu meningkatkan nafsu makan dan meningkatkan absorbsi makanan yang membuat larva lebih aktif bergerak dan sehat, sehingga larva mampu bertahan hidup. Diperkuat dengan pernyataan Lam (1980) bahwa hormon tiroksin mampu meningkatkan nilai kelulushidupan ikan. 


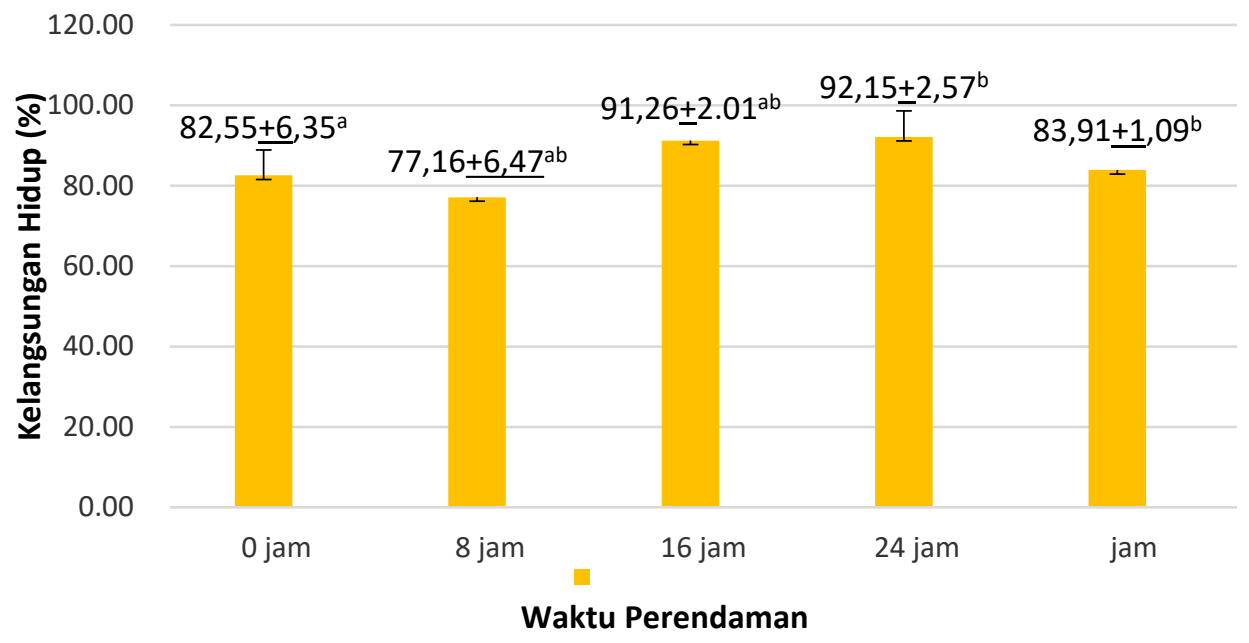

Gambar 4. Grafik Kelangsungan Hidup Larva Gurami Setelah Dilakukan Perendaman Hormone Tiroksin $0.1 \mathrm{mg} / \mathrm{L}$ Dengan Waktu Berbeda.

Keterangan : Data nilai kelangsungan hidp larva merupakan hasil rata-rata $(\bar{x} \pm$ SD $)$. Angka yang diikuti huruf kecil superscript yang berbeda menunjukan perbedaan signifikan $(\mathrm{P}<0.05)$.

\section{DAFTAR PUSTAKA}

Agusnimar dan Rosyadi. 2015. Growth and Survival of Kryptopterus lais treated with thyroxine hormone. Jurnal Akuakultur Indonesia 14, 38-4.

Alkatiri, N. J. 2016. Efektivitas Pemberian Hormon Tiroksin Terhadap Daya Tetas, Pertumbuhan Dan Kelangsungan Hidup Larva Ikan Gurami (Osphronemus gouramy). Skripsi. Universitas Lampung. Lampung.

Andriawan, R., F. Basuki dan T. Yuniarti. 2020. Pengaruh Lama Waktu Perendaman Hormon Tiroksin (T4) Terhadap Pertumbuhan dan Kelulushidupan Larva Ikan Nila Puti (Oreochromis niloticus). Jurnal Sains Akuakultur Tropis 4 : (1) : 51-60.

Arifin, O. Z., Imron., Muslim, N., Hendri, A., Aseppendi dan Yani, A. 2017. Karakteristik Fenotipe dan Genotipe Ikan Gurami, Osphronemus gourami, Strain Galunggung Hitam, Galunggung Putih dan Hibridanya. Jurnal Riset Akuakultur 12 (2) : 99-110

Blanton, M.L., and Specker, J.L. 2007. The Hypothalamus-PituitaryThyroid (HPT) Axis in Fish and Its Role in Fish Development and Reproduction. Crit. Rev. Toxicol 37 (1-2) : :97-115

Budiana dan Rahardja, B. S. 2018. Teknik Pembenihan Ikan gurami (Osphronemus gouramy) Di Balai Benih Ikan Ngoro, Jombang. Journal of Aquaculture and Fish Health, 7(3) : 90-97.

Dewi, R.R.S.P. 2006. Strategi Peningkatan Produksi Benih Ikan Budidaya melalui Penggunaan Hormon Tiroid. Media Akuakultur, 1(2) : 55-57. 
Dolomatov, S.I., Kubyshkin, A.V., Kutia, S.A., Zukow, W. 2013. Role of Thyroid Hormones In Fishes. Journal of Health Science 3 (9) : 279-296.

Effendi, M.I. 1979. Metode Biologi Perikanan. Yayasan Pustaka Indonesia. Jakarta.

Ghofur, M., Sugihartono, M., Arfah, J. 2016. Uji Efektifitas Ekstrak Kunyit (Curcuma domestical) Terhadap Daya Tetas Telur Ikan Gurami (Osphronemus gouramy). Jurnal Ilmiah Universitas Batanghari Jambi, 16(1) : 68-76.

Khalil, N.A., Allah, H.M.M.K., Mousa, M.A. 2011. The Effect of Maternal Thyroxine Injection on Growth, Survival, and Development of The Digestive System of Nile Tilapia (Oreochromis niloticus) Larvae. Advances in Bioscience and Biotechnology, 2 : 320-329.

Kurniawan, O., Johan, T. I., Setiaji, J. 2014. Pengaruh Pemberian Hormon Tiroksin (T4) Dengan Perendaman Terhadap Pertumbuhan dan Tingkat Kelulushidupan Benih Ikan Gurami (Osphronemus gouramy). Jurnal Dinamika Pertanian, 29(1) : 107-112.

Manurung, Septiana., Basuki, Fajar., dan Detrina. 2017. Pengaruh Lama Perendaman Hormon Tiroksin Terhadap Daya Tetas Telur, Pertumbuhan, Dan Kelangsungan Hidup Larva Ikan Mas Koki (Carassius auratus). Journal of Aquaculture Management and Technology, 6(4) : 202-211.

Muslim dan Yonarta, D. 2017. Penetasan Telur Ikan Gabus (Channa striata) Dalam Media Inkubasi Dengan Lama Pemberian Oksigen (Aerasi)
Berbeda. Jurnal Perikanan Tropis, 4(2) : 187-198.

Muslim, Sasanti, A.D., dan Apriana. 2019. Pengaruh Lama Perendaman Hormon Tiroksin terhadap Pertumbuhan Larva Ikan Gabus (Channa striata). Journal of Aquaculture of Science 4 (1) : 0111.

Nayak, P.K., Mishra, T.K., Mishra ,J., Pandey, A.K. 2004. Effect Of Combined Thyroxine And Cortisol Treatment On Hatching Of Eggs, Post-Embryonic Growth And Survival of Larvae Of Heteropneustes Fossilis. Journal of the Indian Fisheries Association, $31: 125-137$

Oktaviani, L., Basuki, F., Nugroho, R.A. 2017. Pengaruh Perendaman Hormon Tiroksin Dengan Dosis Yang Berbeda Terhadap Daya Tetas Telur, Pertumbuhan, dan Kelangsungan Hidup Larva Ikan Mas Koki (Carassius auratus). Journal of Aquaculture Management and Technology, 6(4) : 110-119.

Pasaribu, A. F., Muslim M., Syaifudin, M. 2019. Pengaruh Lama Waktu Perendaman Dalam Larutan Tiroksin Terhadap Pertumbuhan dan Kelangsungan Hidup Larva Ikan Gabus (Channa striata). Jurnal Akuakultur Rawa Indonesia, 7(1) : 25-33.

Pebriyanti, M., Muslim., Yulisman. 2015. Pertumbuhan Larva Ikan Betok (Anabas testudineus) Yang Direndam Dalam Larutan Hormon Tiroksin Dengan Konsentrasi Dan Lama Waktu Perendaman Yang Berbeda. Jurnal Akuakultur Rawa Indonesia, 3(1) : 46-57.

Pramono, T.B dan Marnani, S. 2009. Pola Penyerapan Kuning Telur 
dan Perkembangan Organogenesis pada Stadia Awal Larva Ikan Senggaringan (Mystus nigriceps). Berkala Perikanan Terubuk 37 (1) :1826.

Pranata, Adi., Raharjo, E.I., Farida. 2017. Pengaruh Padat Tebar Terhadap Laju Pertumbuhan Dan Kelangsungan Hidup Larva Ikan Gurame (Osphronemus gouramy). Jurnal Ruaya, 5(1) : $1-6$.

Power D.M., Llewellyn L., Faustino M. et al. 2001. Thyroid hormones in growth and development of fish. Comp. Biochem. Physiol. C Toxicol. Pharmacol. 130 (4) : 447-459

Salvatore D. 2011. Deiodinases : keeping the thyroid hormone supply in balance. Journal of Endocrinology 209 : 259-260

Setiaji, J., dan Johan, T.I. 2012. Pengaruh Hormon Tiroksin (T4) Terhadap Kelulushidupan dan Pertumbuhan Benih Ikan Jambal Siam (Pangasius hypophthalmus). Jurnal Dinamika Pertanian, 27(3) : 189-194.

Soedibya, P.H.T., dan Pramono, T.B. 2018. Budidaya Perairan Tawar. Universitas Jenderal Soedirman. Purwokerto. 70 hal.

Sulistyo, J., Muarifa., Mumpuni, F. J. 2016. Pertumbuhan dan Kelangsungan Hidup Benih Ikan Gurami (Osphronemus gouramy) Pada Sistem Resirkulasi Dengan Padat Tebar 5,7 dan 9 Ekor/Liter. Jurnal Pertanian, 7(2) : 87-93.

Susanti, N. M., Sukendi., Syafriadiman. 2016. Efektivitas Pemberian Hormon Tiroksin (T4) terhadap Pertumbuhan Ikan Pawas (Osteochillus hasselti). Jurnal
Perikanan dan Kelautan, 21(2) : 26-31.

Ulpah, Y., Adriani, M., Murjani, A. 2017. Daya Tetas dan Kelangsungan Hidup Larva Ikan Gurami Pada Padat Tebar Yang Berbeda. Jurnal Akuakultur, 1(1) : 1-12.

Yamano, K. 2005. The Role of Thyroid Hormone in Fish Development with Reference to Aquaculture. JARQ 39 (3) : 161-168.

Zooneveld, N. E., Huisman, A., Boon, J. H. 1991. Prinsip-prinsip Budidaya Ikan. PT. Gramedia Pustaka Utama. Jakarta. 